\title{
Cuando los cuerpos hablan. La corporalidad en las narraciones sobre la violencia sexual en las guerras de la República Democrática del Congo
}

\author{
When Bodies Talk. Embodiment in Narratives on Sexual \\ Violence in the Wars of the Democratic Republic of Congo
}

\author{
Elisa García Mingo \\ Centro Universitario Villanueva, Madrid, España
}

\section{RESUMEN}

Las noticias, los documentales y las campañas mediáticas de la industria humanitaria se han convertido en los principales relatos sobre la violencia sexual sistemática que se ha perpetrado contra las mujeres en la República Democrática del Congo desde el año 1996 hasta el día de hoy. Las narraciones, ya sean políticas o mediáticas, explotan los hechos concretos que tienen que ver con los ataques contra los cuerpos y rara vez dan cuenta del auténtico impacto que tiene la violencia sexual en las vidas de las mujeres, más allá de las lesiones y la enfermedad. Este hecho ha contribuido a forjar la visión, que ya de por sí goza de cierta potencia histórica y está cómodamente instalada en los foros internacionales, que identifica a la mujer congoleña como víctima pasiva, como mero cuerpo violable. Esta visión moviliza la lástima y la compasión en el público general y genera enfoques inmovilistas en los sectores de la ayuda internacional, en lugar de promover marcos que consideren a las mujeres congoleñas como actoras relevantes de transformación social y de construcción de paz. Este artículo analiza las diferentes narrativas que se han puesto a circular sobre la violencia sexual desde la perspectiva de los "cuerpos sociales" con el fin de visibilizar los problemas que surgen del abuso de este tipo de prácticas narrativas.

Palabras clave: Corporalidad; Narrativas; Violencia sexual; Activismo; Testimonio; RDCongo.

\section{SUMMARY}

News, documentaries and humanitarian campaigns in the mass media have become the source of accounts on the systematic violence perpetrated against women in the DRC since 1996. These accounts, whether political or media, exploit the specific facts regarding these attacks on women's bodies, rarely visibilizing the true impact of sexual violence on women's lives. This has helped shape a standpoint - already to some extent historically consolidated and ensconced in international forums - that identifies Congolese women as passive victims, as mere raped bodies. It is a standpoint that mobilises pity and compassion in the public and generates an immobilist approach to humanitarian intervention and international aid, rather than promoting frameworks in which Congolese women are relevant players in peacebuilding. This article analyses the different narratives circulating on sexual violence from the perspective of the "social body," rendering visible problems that arise from the abuse of this type of narrative practice.

Key words: Embodiment; Narratives; Sexual Violence; DRCongo; Advocacy; Witnessing. 


\section{LOS CUERPOS HABLAN, LOS CADÁVERES CALLAN}

Entre 2008 y 2011 desarrollé mi trabajo de tesis doctoral acerca de un grupo de mujeres periodistas congoleñas que comenzaron a usar las ondas de sus radios locales para denunciar los crímenes sexuales que se estaban cometiendo contra mujeres y niñas desde el año 1996. Ondas de Paz, mi tesis, resultó del trabajo de campo que conduje en RDCongo en 2008 y en 2009. Desde entonces, he estado vinculada a este grupo de mujeres ${ }^{1}$. Una de las cuestiones más inquietantes que emergieron de mi trabajo doctoral surgió cuando un intelectual congoleño me preguntó: "¿Y por qué no se habla de los millones de hombres que murieron, que fueron torturados, que fueron obligados a matar?" Le contesté que Ngwarsungu Chiwengo, centroafricana exiliada en los EEUU, había hecho una interesante reflexión sobre los cadáveres congoleños y su fracaso a la hora de interpelar a la comunidad internacional $^{2}$ (Chiwengo 2008) sobre su intervención en la RDCongo. A raíz de esa reflexión, comencé a elaborar la idea de "los cuerpos que hablan" y sobre cómo se hace hablar a los cuerpos violados de las mujeres congoleñas según los intereses políticos de quien las hace hablar. Sirva este propio artículo como ejemplo de una forma de hacer hablar a esos cuerpos.

Este trabajo pretende contribuir a las grandes reflexiones de la Antropología Feminista, que se han ocupado de teorizar, junto a otra ramas de la antropología, como la Antropología del Cuerpo, la Antropología de la Violencia o la Antropología del Desarrollo sobre conceptos relevantes para este trabajo como son: el cuerpo, la violencia, la memoria y el testimonio. Para la noción de cuerpo, trabajo a partir de la idea de Mariluz Esteban que nos insta a mirar a los cuerpos como "metáfora del sistema social" (2004: 20), por lo que si queremos hacer análisis de sus cuerpos y sus sufrimientos, tendremos que atender a los contextos socio-políticos en los que se producen esos cuerpos (Esteban 2004: 26). El otro gran fenómeno que exploro en este artículo es el de "memoria", el cual entiendo, siguiendo a Teresa del Valle (1999: 8), como "la capacidad humana de diseñar procesos para situar las experiencias en el presente en un momento concreto (...) que se ejercita de distintas maneras: individual, grupal, explícita o mediante procesos indirectos". Esta autora estudia, apoyándose en otras autoras de corte feminista, los procesos de construcción de la memoria y analiza cómo "se sedimentan en imágenes culturales y en prácticas los fenómenos históricos de larga duración" (Del Valle 1999: 10). Para ello, Del Valle encuentra en el cuerpo un vehículo fundamental en el que se practica la memoria, lo que ella denomina "la memoria del cuerpo" y la "memoria encarnada" (Del Valle 1999).

En mi caso de estudio, hay varios fenómenos que están estructurando el sistema social de las mujeres congoleñas y de sus cuerpos. En primer lugar, una de las grandes experiencias de las mujeres congoleñas del siglo XXI es la vivencia de la(s)

\footnotetext{
${ }^{1}$ En 2013 y 2014 he conducido trabajo de campo con Caddy Adzuba en sus giras por España. Colaboro actualmente con el proyecto que se desarrolla en RDCongo: Mujeres al Teléfono (2013-2015).

${ }^{2}$ El artículo de N. Chiwengo se titula "Cuando los cadáveres no logran hablar". A ello hace referencia el título de este artículo,
} 
violencia(s) sexual(es), es decir, no sólo la violación, sino también el secuestro y abuso sexual en cautiverio, el embarazo forzado y la esclavitud sexual. En segundo lugar, estos crímenes sexuales han cobrado una dimensión política y una notoriedad internacional tan amplia, que en la última década la violación es la gran experiencia vital de las mujeres congoleñas a la vez que la perpetración de la misma es la parte que le toca a los hombres congoleños. Este retrato simplista encaja con la descripción de la RDCongo — recogida en textos literarios, humanitarios, mediáticos o políticos- como un país patológico y disfuncional, necesitado de las potencias internacionales para autogestionarse y poner fin a los conflictos.

Este artículo pretende pues problematizar las diferentes narrativas que existen sobre los crímenes sexuales en la RDCongo, partiendo de la premisa de que el (ab)uso de los cuerpos para explicar la vulneración de derechos humanos de la población civil en la RDCongo no ayuda a mejorar la situación de las mujeres y niñas, sino que la destrucción de los cuerpos, convertida en un espectáculo, impide entender los hechos que originaron la situación (Malkki 1996: 388) y dificultan la tarea de desentrañar las causas reales y las consecuencias sutiles de la misma. Pretendo hacer esta reflexión con cierta urgencia, puesto que estamos presenciando cómo se está construyendo la memoria del feminicidio congoleño ahora, ante nuestros ojos. Más que estar ante "memorias encarnadas", como las describe Teresa del Valle, estamos ante la "encarnación de la memoria" que se produce a partir de cuerpos con memoria. Para muchos y muchas, encarnar la memoria parece ser la única manera de urecordar el presente" (García Mingo 2011).

\section{ESTA NOCHE, LOS HORRORES DE LA RDCONGO EN TELEVISIÓN ESPAÑOLA}

Con profunda gratitud y gran humildad me presento ante ustedes para darles las gracias desde lo más profundo de mi corazón. Mediante este prestigioso galardón, han elegido reconocer la labor pacífica de lucha contra la violencia sexual de la que son víctimas las mujeres en tiempos de guerra, en la zona oriental de la República Democrática del Congo, y la lucha contra la pobreza. Es un gran honor para mi humilde persona. Hubiese querido que este honor fuera recibido por las miles de mujeres congoleñas, víctimas de la guerra y de la violencia sexual, despojadas de todo honor desde que sus cuerpos fueron transformados en campos de batalla. Hoy, la mujer congoleña víctima de los conflictos armados, violentada y violada, ha perdido toda su dignidad y vive en la deshonra. Ella, cuyos órganos genitales fueron sometidos a los ultrajes más viles, condenada a la esclavitud sexual y rechazada por su propia comunidad, lleva 18 años sufriendo: 18 años de tortura, 18 años de destrucción, 18 años de huida errante y desplazamiento, 18 años de pobreza extrema. ¿Durante cuánto tiempo más vamos a seguir insensibles al dolor de las mujeres violadas en la RDCongo? Las mujeres congoleñas, heridas en cuerpo y alma, reclaman justicia y reparación... ${ }^{3}$

Caddy Adzuba lanza un poderoso y estudiado discurso al público de los Premios Príncipe de Asturias. El Rey Felipe VI escucha con regia parsimonia. A su lado, la Reina Letizia, asiente con cierta emoción. España se está exponiendo en prime-time

\footnotetext{
${ }^{3}$ Fragmento del discurso de Caddy Adzuba en la Ceremonia de los Premios Príncipe de Asturias 2014 .
} 
a la cruda realidad de las cifras de las repetidas guerras de la RDCongo y del conflicto en espiral en el que miles de mujeres están perdiendo "su honor y dignidad". Caddy Adzuba, la laureada esta noche con el Premio Príncipe de Asturias de la Concordia 2014, es congoleña y periodista, y una refinada activista de los derechos humanos. Todo está listo para que lleguen ciertas píldoras del horror congoleño a los españoles de a pie. Ella, con su francés impecable y su vestido en pagne, cuida el ritmo, el tono y los datos. 6.000.000 de muertos. 500.0000 de mujeres violadas. La periodista congoleña recoge en un tiempo récord poco mayor a 9 minutos las ideas clave. Tiene que capitalizar el momento y llegar a la audiencia europea. Con elocuencia y precisión, va desgranando las ideas fundamentales del toolkit activista: el origen del conflicto en conexión con la explotación y comercio ilícito de los minerales del subsuelo congoleño; las consecuencias atroces de la guerra en la población civil, con especial crueldad en las mujeres; el olvido internacional y la impunidad de los crímenes a gran escala. Consigue poner en la mesas de la cena de los españoles los horrores contemporáneos de la RDCongo. La periodista congoleña reivindica el fin del conflicto, pero los españoles en sus casas se preguntan, quizá, mirándose unos a otros... ¿de qué guerra habla?

La RDCongo es un inmenso país con unos vastísimos yacimientos minerales y una gran riqueza natural; asimismo, cuenta con una larga historia de abusos contra la población civil. El país africano entró en el siglo XX sumido en uno de los regímenes más abyectos de la era contemporánea: el mandato de Leopoldo II y acabó el siglo XX atrapado en las guerras más cruentas desde la Segunda Guerra Mundial: las "guerras del Congo". El siglo XX ha traído a los congoleños un sufrimiento social a gran escala. La empresa extractiva de caucho del monarca belga Leopoldo II provocó la muerte de varios millones de congoleños, como resultado de la enfermedad, el asesinato, la tortura y la enfermedad (Dunn 2003: 45); el Zaire poscolonial de la era Mobutu empobreció a los congoleños debido a un régimen de cleptocracia; y las guerras, desde 1996 hasta la actualidad, han arrojado cifras estremecedoras: más de 5.5 millones de víctimas mortales, 4 millones de desplazados, 500.000 refugiados (IRC, 2008). Pese a que el país está oficialmente pacificado desde 2003 por los acuerdos de paz de Sun City, en la región de los Kivus, al este del país, la guerra continúa, convertida en una de las guerras más complejas y duraderas del mundo.

La "Guerra de los Kivus" o "Tercera Guerra del Congo" (2003-actualidad) se ha caracterizado por la diseminación de la violencia, la proliferación de grupos armados con alianzas volátiles, los sucesivos intentos frustrados de negociar la paz y por la perpetuación de una crisis humanitaria que ha motivado el empeoramiento de la vida de la población de los Kivus. Además, las causas que motivaron el conflicto siguen sin resolverse. Continúan las actuaciones arbitrarias y opresivas sobre la población civil de políticos, fuerzas de la seguridad, instituciones. No se han resuelto los conflictos locales por la tierra y por el poder; y persiste la corrupción a todos los niveles de la estructura política. En este entramado es donde encaja la perversa cadena de expolio de los recursos naturales (oro, diamante, coltan), que ha contribuido a financiar la guerra y que es una de las causas de los abusos contra la población congoleña.

Entre los ataques cometidos contra civiles, han llamado la atención internacional los crímenes sexuales cometidos contra las mujeres y las niñas congoleñas. Algunos expertos hablan de "la pandemia de la violencia sexual", definiendo la situación en 
sus informes como "un feminicidio obsceno e insanamente salvaje" (Lewis y Ensler 2009). Tanto los grupos armados como las fuerzas de seguridad gubernamentales han usado la violencia sexual en sus diversas formas como arma de guerra. Las mujeres y las niñas han sido víctimas de crímenes sexuales ejercidos como parte de estrategias militares racionales destinadas a castigar, avergonzar, torturar, atemorizar y controlar, tanto a las mujeres como a sus comunidades (Erikssen Baaz y Stern 2009).

No hay cifras definitivas, pero los expertos aseguran que son más de 500.000 las víctimas de estos crímenes. En algunas zonas de la región del Kivu, 3 de cada 4 mujeres han sido violadas (MSF, 2014). El sistema de justicia congoleño es incapaz de hacer frente a los problemas de la violencia sexual y las mujeres supervivientes de las violaciones no disponen de la asistencia y la protección necesaria, por lo que las consecuencias de la violencia se multiplican y se agravan. Además de vivir con el estigma $\mathrm{y}$, en ocasiones, el repudio, viven en un régimen de impunidad que ha tenido un impacto hasta ahora pobremente descrito: el aumento de violaciones perpetradas por civiles. Las violencias sexuales funcionan como un metalenguaje que devalúa a la mujer y con ella a toda su comunidad. La violencia ejercida sobre los cuerpos de las mujeres es «una metáfora antigua y performativa de gran poder semántico y dramático pues la generación del daño sobre el cuerpo es el equivalente sensorial a la muerte" (Scarry 1985: 61).

Muchos actores en la región han capitalizado la violencia sexual para elaborar su lucha, por lo que ha cobrado especial importancia la crudeza del mensaje, el horror del relato y el impacto de la imagen. Expertos en violencia sexual que buscan hacer avances en el Derecho Internacional; activistas de los derechos de la mujer que encuentran su particular caballo de batalla en las víctimas congoleñas; activistas de la sociedad civil congoleña, que hastiados de atropellos de toda índole encuentran en el feminicidio la metáfora de la destrucción de la sociedad. Si las heridas y los cadáveres de los hombres no han logrado "hablar" sobre el conflicto, lo han hecho los cuerpos violados de las mujeres congoleñas, que a pesar de tener un dolor más invisible e interno, han conseguido tener una voz audible en la esfera humanitaria internacional. Este trabajo concibe los cuerpos de las mujeres como "cuerpos sociales", en el sentido de que "la guerra transforma los cuerpos individuales en cuerpos sociales" (Olujic 1998:46) tanto para víctimas y perpetradores como para otros actores que operan metafóricamente sobre los cuerpos de las mujeres.

Casi todos los relatos del horror congoleño tienen una gran corporalidad; incorporan términos médicos, incluyen descripciones muy elaboradas de las heridas y lesiones, detallan el impacto sobre los cuerpos, describen las herramientas y métodos de vejación empleados y usan otros tantos recursos que les permitan narrar el horror al milímetro con el fin de (con)mover. Hasta hoy, en parte alimentados por la prensa occidental, los crímenes sexuales han sido descritos como brutales, salvajes y obscenos cayendo en la mera descripción de los aspectos físicos de la violencia, pasando por alto su trascendencia, su contexto y su significado, corriendo el riesgo de degenerar en un teatro de pornografía de la violencia en el cual «el impulso voyeurístico subvierte el amplio proyecto de testimoniar, criticar y escribir contra la violencia, la injusticia y el sufrimiento" (Scheper-Hughes y Bourgois 2004:1).

Los relatos habituales sobre los ataques no suelen dar cuenta del coste real de la violencia más allá de la miseria corporal, como son: el epílogo psicológico, la 
disfunción familiar o la depauperización de víctimas y comunidades que viven en un régimen ya de por sí deficitario. Las cifras y las imágenes del horror han servido para alimentar informes que suelen caer en la lógica del "humanitarismo deshistorizante" (Hunt 2008: 238). Las narrativas, construidas a partir de testimonios de víctimas o por testigos privilegiados de los mismos, suelen recubrirse de una oralidad descarnada y centrarse en la destrucción física de los cuerpos individuales, metáfora del cuerpo social enfermo. El mensaje consiste en que las sociedades patológicas, como la congoleña, producen cuerpos enfermos; los cuerpos enfermos deben ser diseccionados y tratados; en definitiva, intervenidos.

\section{LA PROFANACIÓN DE LAS VAGINAS Y LOS CUERPOS QUE RECUERDAN}

Los cuerpos nunca son sólo amasijos de músculos, huesos, órganos, son "cuerpos sociales", usados y representados de manera específica en cada cultura, "objeto de los sistemas de coerción, de inscripción legal y de intercambio económico" (Grosz 1994: 18). El cuerpo de las víctimas es una unidad potente de poder espacial, que combinándose con otras unidades genera una red de "espacios de dominación" (Feldman 1991: 8) idóneos para quienes ejercen la violencia. El cuerpo es un objeto social sobre el que se inscribe el poder y dichas inscripciones, que toman forma de rostros ajados, fístulas traumáticas o cicatrices, nos permiten rastrear las subjetividades y las herencias socio-culturales y políticas de los perpetradores, que usan diferentes técnicas para dejar su mensaje, su recordatorio constante de la dominación (Olujic 1998: 42) sobre las víctimas y sus comunidades. Es muy sugerente para este caso tomar la metáfora que usan varios autores, que sostiene que "los cuerpos recuerdan" (Fassin 2007; Del Valle 1999), en este caso, recuerdan la violencia. El ejercicio de la violencia sexual sobre los cuerpos implica un uso y un consumo ideológico de los cuerpos, guiado por ideas patriarcales o violentas, lo que nos permite observar en los cuerpos destruidos las "biografías políticas" que éstos acumulan (Feldman 1991: 9). Grosz propone la metáfora del cuerpo como palimpsesto, como crónica histórica de trazos borrados, reescritos, enfatizados, haciendo del cuerpo un texto complicado de leer (1994: 117). De esta manera, los cuerpos de las víctimas del feminicidio congoleño tienen varios rastros de violencias pasadas y de las violencias presentes.

\section{CUERPOS VIOLADOS, VIDAS INTERRUMPIDAS}

Una víctima relata el sufrimiento que sobreviene después de la violación, por la enfermedad y la vergüenza: "Veo cómo se pudre el banano en el árbol, es muy doloroso verlo. Mis hijos son demasiado pequeños para cogerlo y lloran de hambre, pero no tengo fuerzas para levantarme. Estoy sangrando y mis hijos morirán de hambre ${ }^{4} \ldots$

El testimonio de esta mujer revela que el impacto de los crímenes sexuales en sus vidas no es sólo la destrucción de los cuerpos, sino la incapacidad de abordar la cotidianidad de la guerra (Nordstrom y Robben 1995: 3). Por otro lado, ilustra una

\footnotetext{
${ }^{4}$ Testimonios recogidos en investigaciones internas de AFEM-SK.
} 
experiencia paradigmática de la vivencia que tienen las mujeres durante la guerra (Amnistía Internacional 2004: 11). Estas prácticas sirven a los perpetradores — grupos rebeldes, fuerzas de la seguridad congoleña y civiles- para: intimidar a civiles que trabajan o controlan minas de casiterita, coltan u oro; sembrar el terror para desplazar a poblaciones que ocupan territorios importantes a nivel estratégico; o destruir el capital social de la comunidad enemiga.

La violencia contra de las mujeres en la RDCongo y especialmente en la región de los Kivus ha adquirido una magnitud inimaginable. Las mujeres son responsables de la economía del hogar, del abastecimiento de alimentos y de agua; por eso se desplazan cada día hasta zonas donde corren el riesgo de sufrir ataques sexuales (Amnistía Internacional 2004: 58), ser secuestradas o perder sus bienes o dinero. Incluso en los campos de refugiados, las mujeres siguen sufriendo ataques y violencia sexual (MSF, 2014). Este tipo de abusos ha producido a las mujeres un aumento de la mortalidad, la infección por el VIH y otras Infecciones de Transmisión Sexual (ITS) y las lesiones genitales, como la tristemente conocida "fístula traumática" (Hunt 2008).

Sin embargo, el gran problema para las víctimas de estas violencias se produce en el plano económico y social. Como resultado del ataque, se produce una pérdida de vínculos comunitarios que les genera exclusión, pérdida de tierras y empleo. El caso de las víctimas más jóvenes, las niñas y adolescentes, es quizá el más sangrante; su destino estará marcado para siempre por el abuso, ya que tienen dificultades para encontrar marido, abandonan los estudios, son repudiadas por su propia familia y, en ocasiones, tienen que criar a un bebé nacido de la violación cuando ellas mismas son aún niñas (Human Rights Watch 2009: 5). Los hijos y las hijas nacidos del abuso, llamados "lagartos" o "niños malditos" reflejan el impacto de la violencia en las vidas de las mujeres. Las familias de las víctimas, incluso ellas mismas, ven a los bebés concebidos como resultado de la violación como una maldición para el clan y la comunidad; mientras que las madres pueden ser aceptadas de nuevo en el seno de sus comunidades, es raro que estos niños y niñas lo sean. Muchos de estos y estas menores son abandonados por sus madres, por lo que es normal que se críen en las calles de las ciudades junto a otros huérfanos y se dediquen a la mendicidad o al pequeño crimen, convirtiéndose en maibobo, como se llaman a los niños y las niñas de la calle.

En las calles de la ciudad, en las sedes de las ONGs locales y en los hospitales hay muchas mujeres que han optado por no volver a sus aldeas, por la vergüenza y el miedo al repudio. Otras tantas intentaron volver, pero fueron rechazadas por sus maridos o por su familia, lo que obligó a emigrar a las ciudades y núcleos urbanos buscando algún empleo. Algunas de ellas recalan en centros de víctimas creados por ONGs locales e internacionales, en los que siguen programas de formación y de reinserción. Muchas de ellas tienen que afrontar el estigma de ser víctimas, lo que se traduce en insultos en las calles de las aldeas, en acoso por parte de los hombres del pueblo o en la imposibilidad de casarse. Algunas mujeres cuentan que han tenido que ir a los centros de tránsito porque la convivencia con sus maridos tras haber sufrido una violación era insoportable, y en algunos casos se traducían en cuadros de maltrato doméstico. Durante mi trabajo de campo conducido en 2009, una de las mujeres relataba que su marido le exigía que participara en todos los programas de 
las ONGs que daban asistencia a víctimas con el fin de beneficiarse de los bienes que les daban a las víctimas. "¿Me has traído algo?" solía preguntar, o "he visto que las mujeres de los Nagabo han conseguido mantas y quinqués de las ONGs; itú lo has pedido?». Ella luchaba cada día por olvidar su condición de víctima, por trabajar la tierra y volver a sus tareas, pero la actitud de su marido le impedía olvidar el fatídico día.

\section{LA PROFANACiÓN DE LAS VAGinaS COMO LENGUAJE}

La violación de guerra se ha convertido en una indiscutible arma de humillación masiva de las mujeres y los pueblos. ¡Silencio, estamos violando! ¡Silencio, estamos asesinando! ¡El silencio mata! ¿Acaso habrá un tercer sexo? El de las vaginas olvidadas de las guerras olvidadas...

[La Profanación de las Vaginas, Boyla. 2005]

No podemos ignorar que la violencia, como sucede en otros lugares, no está restringida a la guerra, sino que tiene raíces en los tiempos de paz (Olujic 1998:31). Además de los crímenes sexuales, la impunidad, la exclusión de las mujeres de la vida política, el clima de terror doméstico y otras instituciones socioculturales perpetúan la devaluación y cosificación de las mujeres en esta región. No podemos olvidar que los crímenes sexuales ejercidos contra mujeres y niñas son polisémicos, puesto que sirven para varios propósitos: como táctica bélica, como botín de guerra y como mensaje simbólico enviado a los hombres, que son conquistados a través de las mujeres contaminadas (Eriksson Baaz y Stern 2009: 498).

María Olujic, con sus trabajos fundacionales conducidos en Bosnia y Croacia en los años 90 sobre violencia sexual contra mujeres en contextos de conflicto armado, nos da pistas para entender la intersección entre cuerpo y violencia, cuerpo y territorio y violencia y etnicidad. A pesar de que hay cuestiones que difícilmente podamos aplicar en este caso, algunas de sus apuestas analíticas son pertinentes para el caso del feminicidio de la RDCongo. Para esta autora, el mensaje que pretende dejar el perpetrador de la violencia sexual es una inscripción de marcas visibles de etnicidad o nacionalidad en los cuerpos, "unas inscripciones que se relacionan directamente con las tensiones particulares de la región" (Olujic 1998: 43). Para el caso concreto de la región de los Grandes Lagos, esta afirmación cobra gran relevancia y actualidad, puesto que el debate de la etnicidad es fundamental en la vida política de los Kivus. Según Olujic, la lógica de la perpetración de los crímenes sexuales ha de ser examinada en términos de su significación local, desde el lenguaje de la fecundidad, el parentesco y el cuerpo de las mujeres congoleñas. Por ese motivo, es más relevante que nunca realizar trabajo de campo basado en técnicas de observación y de narración.

En una entrevista que conduje con la coordinadora de AFEM-SK ${ }^{5}$, Zakia Mweze, ésta afirmaba que antes de las guerras de los años 90 no tenían una voz en el suajili del oriente congoleño para decir "violación". Tomaron del suajili tanzano la palabra

\footnotetext{
${ }^{5}$ Entrevista conducida por la autora en Octubre de 2008 en Bukavu (RDCongo) en el marco del trabajo de campo conducente a la Tesis Doctoral
} 
ubakaji (violencia sexual contra las mujeres) para referirse a una nueva realidad que, según ella, había sido "importada" por los soldados de los ejércitos extranjeros cuando comenzaron las crisis de los Grandes Lagos en 1994. Sin embargo, la realidad del Kivu del siglo XXI nos habla de la normalización de la violencia sexual; de hecho, los propios soldados y miembros de los grupos armados, perpetradores de la ubakaji, hacen deliberaciones éticas sobre ésta, distinguiendo entre la viol ya pose (violación por lujuria) y considerada como violación normal, desde una óptica de opresión patriarcal local previa, y la viol ya mabe (violación cruel) (Eriksson Baz y Stern 2009: 510), empleada como instrumento político en el contexto del conflicto armado, en el sentido dado por Olujic cuando afirma que la guerra no genera la violación sino que transforma sus usos (1998: 43). El viol ya mabe es la transformación del viol ya pose puesto que usa la violencia sobre los cuerpos de las mujeres como estrategia para sembrar el terror en el colectivo, y por eso, la gran mayoría de los ataques que se producen son violaciones grupales y se registran, constantemente, testimonios de "mujeres que admiten haber sido violadas mediante la inserción de objetos como bastones, botellas, bananas, fusiles y brazos de mortero ${ }^{6}$ recubiertos de pimienta" (Bisimwa et al. 2004). Los mensajes que se inscriben sobre los cuerpos de las mujeres son descifrados por sus comunidades porque éstas comparten con los perpetradores los conceptos de honor, vergüenza y sexualidad que se asocian a los cuerpos de las mujeres en tiempos de paz (Olujic 1998: 31).

\section{CUERPOS ELOCUENTES, PATOLOGÍAS FUNCIONALES}

-No puedes llegar siquiera a imaginarte las últimas noticias que nos llegan del interior. Está ocurriendo algo que nunca antes había sucedido; ha llegado un grupo de mujeres diciendo que les han quemado los genitales. Las violaron, después les rociaron con gasolina en sus sexos y luego les prendieron fuego. Conocíamos a mujeres a las que les dispararon en la vagina. Los ruandeses eran conocidos por eso, solían destruir los genitales de las víctimas después de la violación, con bayonetas o pistolas... pero nunca habíamos oído algo tan terrible. Una sabía quién era el perpetrador por la forma de violar que tenían los hombres de un grupo u otro. Por ejemplo, los burundeses les introducían a las mujeres objetos en la vagina, jllegamos a oír historias de mujeres a las que les habían metido ramas!

La violencia sexual como sinécdoque del horror congoleño ha ido convirtiéndose paulatinamente en la idea central del discurso sobre las guerras en el Congo, a pesar de que hay muchas otras muchas consecuencias de la violencia, como son las matanzas, los incendios de aldeas, el trabajo forzoso, el reclutamiento de menores soldado y la tortura no sexual (Auteserre 2012). Este tipo de historia de violencia tiene un impacto emocional alto, por varios motivos: tiene gran corporalidad, apela al horror de dañar a sujetos vulnerables, encaja en los estereotipos que circulan sobre la salvajería del África Negra y resuena en todas las audiencias porque el abuso sexual es una experiencia cotidiana para muchas mujeres. Estudiar cómo pivotan las narrati-

\footnotetext{
${ }^{6}$ En todos los hogares de la región hay morteros para machacar la mandioca para convertirla en polvo de mandioca para hacer el $f u f u$, la pasta de mandioca.

${ }^{7}$ Entrevista a activista congoleña conducida por la autora en 2010.
} 
vas actuales sobre la RDCongo en torno a la idea de los cuerpos maltrechos nos lleva a revisar algunos debates actuales de la Antropología contemporánea, como son, las políticas de la memoria, el status del testimonio, la industria humanitaria, la pornografía de la violencia o las etnografías de medios y además nos permite "reescribir la habitual narrativa de la atrocidad en relación a las urgencias políticas del presente" (Hunt 2008: 232).

\section{"CONGO: EXPOSICIÓN BRUTAL"}

En Enero de 2015 se ha inaugurado en Liverpool bajo el título Congo: Brutal Exposure, una reedición de la obra fotográfica de Alice Seeley Harris. Una vez más, se dan a conocer al público general las "fotografías del shock" de principios del Congo de Leopoldo II. Algunas de estas fotos han viajado y "han sido recicladas, reempaquetadas y remarcadas una y otra vez" (Hunt 2008: 222). En 1907, la filial londinense de la Congo Reform Association, organización creada para denunciar los horrores del régimen del rey belga en el país africano, vendió unas 10.000 copias de un catálogo Cámara y Crimen del Congo, que incluía veinticuatro fotografías de Alice Seeley Harris (Hunt 2008: 221). Curiosamente, pocas campañas actuales se hacen eco de estos materiales y de estos hechos. Así, la ausencia de historización en las campañas humanitarias actuales nos obliga a examinar el olvido histórico, y "las oportunidades perdidas de trabajar con "los detritos tóxicos de la colonia a la hora de producir historias urgentes y efectivas" (Hunt 2008: 221).

De la misma manera que se reeditan las fotografías, la historia de la violencia en RDCongo, se repite una y otra vez. Violencias del pasado y del presente se solapan y entremezclan, generando un aleph ahistórico de violencias y relatos de la violencia. Sin embargo, hay algunos cambios en el guión. Hasta ahora, el relato de las mujeres violadas había sido silenciado (Auteserre 2012). Según Nancy Hunt, que ha documentado el itinerario seguido por la colección de "imágenes del shock", las fotografías de mutilados desviaron el interés de una modalidad de violencia mas escondida, táctil y fuera de lo evidente: la violencia sexual (Nancy Hunt 2008: 223). En los archivos de principios del siglo XX, ya se recogían testimonios de víctimas de violencia sexual en Congo: "Quedan registros acústicos de memorias vívidas de formas de violencia sexual y transgresora: centinelas que obligaban a madres a tener relaciones con sus hijos, a padres con sus hijas, parientes con parientes. De particular mención son las historias de los centinelas que se divertían metiendo palos en las vaginas de mujeres" (Boelaert et al. 1996: 211 en Hunt 2008: 224). Estas historias parecen la clarividente precuela de las prácticas de destrucción de las vaginas y los cuerpos de las mujeres congoleñas que (re)aparecerían a finales del siglo XX en el este de la RDCongo.

A principios del siglo XX, como se puede apreciar en las fotografías de Seeley Harris, las viñetas gráficas de la revista Punch (1906) y los textos de Roger Casement (1904) y Mark Twain (1905), ya existía un reconocimiento del horror congoleño. De hecho, la RDCongo es un caso único, porque desde su creación ha sido hipertextualizado, "siendo para muchos el "corazón de África", la sinécdoque simbólica del África subsahariana" (Dunn 2003: 8). Mientras que no son abiertamente racistas, muchos relatos sobre la RDCongo siguen reduciendo la compleja política del país africano a 
un drama simple y maniqueo (Stearns 2011:22). Es muy interesante volver sobre los discursos que han existido sobre el Congo colonial, porque las narraciones de los acontecimientos actuales pueden verse como la extensión, hasta cierto punto, de aquellas tradiciones y prácticas discursivas.

Según Mbembe (2001: 1) "el discurso sobre África casi siempre se despliega en el marco de un meta-texto sobre lo animal, para ser exactos, sobre la bestia: su experiencia, su mundo, y su espectáculo". Así, la vida de los africanos tiene que caer necesariamente sobre una de las dos posibilidades: el signo de la bestia o el signo de la víctima. Las narrativas sobre Congo que más han predominado han sido las del "Sufrimiento atroz" (Dunn 2003: 66), construida sobre la imagen imborrable del Corazón de las Tinieblas, que se ha convertido en una tradición narrativa que enmarca todo lo que proviene del Congo en el primitivismo, el atraso y la irracionalidad (Dunn 2003: 5).

\section{RDCONGO: UN PAÍS ENFERMO}

Kai Koddenbrok ha hecho un extenso trabajo sobre las agencias humanitarias como grandes productoras de conocimiento sobre la RDCongo. Para este politólogo de la Universidad de Duisburg-Essen, las agencias humanitarias y Think Tanks han contribuido a elaborar una imagen problemática del país centroafricano que tiende a la simplificación y al reduccionismo. Según este autor, a lo largo de la última década, el foco sobre los Kivus como el "crisol" del conflicto ha reforzado y mantenido la perspectiva de que la RDCongo es un estado fallido, una entidad inexistente (Koddenbrock 2014: 671). En un trabajo anterior, Koddenbrok afirma que en el origen de estas prácticas narrativas está la necesidad que tienen las grandes potencias mundiales de legitimar su intervención en la región (2012: 549). Una de las estrategias narrativas reduccionistas es aquella que patologiza a la sociedad congoleña, haciendo parecer a la RDCongo como el infierno en la Tierra, plagado de muerte y violación. El paradigma terapéutico de la intervención patologiza toda una población caracterizándola como irracional y se basa en la idea de que los individuos, las comunidades y las sociedades está traumatizadas por la guerra. Para elaborar el argumento del Congo patológico e irracional, la violencia necesariamente debe ser narrada desde «la óptica de la barbarie esencialista y racializada" (Koddenbrock 2012: 550).

La historiografía reciente retrata al Congo post-Mobutu como un Corazón de las Tinieblas en el que se prolonga la barbarie que ejercía el colonizador y se retrata al país como un continuum de muerte y tortura. Esta afirmación de Koddenbrok es cierta con matices, en el sentido de que los relatos que se han puesto a circular se elaboran más bien a partir de lo que podríamos llamar la imagen de la "brutalidad racional" puesto que hay un claro planteamiento de las causas, las consecuencias y los actores del conflicto. Con la "brutalidad racional" me refiero al discurso repetido hasta la náusea por todos los actores que ha convertido a la idea de "la violación como arma de guerra" y el "cuerpo de las mujeres como campo de batalla" en lugares comunes como RDCongo que se han desemantizado y se han convertido en eslóganes repetidos que requieren del sufrimiento burocratizado de los cuerpos para conmover al público. 
Los crímenes sexuales han ido pasando de ser violencias invisibles - como explica Hunt (2008) al referirse a los crímenes de la era de Leopoldo II - a crímenes hipervisibilzados. De esta manera, los crímenes sexuales, un día silenciados y obviados en el marco del conflicto congoleño, antes explicado mediante la narrativa del conflicto étnico y sus conexiones con el Genocidio de Ruanda, se han convertido paulatinamente en el "rasgo característico y central del discurso sobre el Congo" (Auteserre 2012: 8). Chiwengo se preguntaba en 2008: "Si la violación y las heridas de los hombres fracasa a la hora de hablar, ¿podrá el dolor invisible e interno, como la violación de las mujeres, hablar?". La respuesta a su sugerente respuesta es afirmativa, como arroja el trabajo de campo que realicé en RDCongo en 2008 y en 2009.

Las visitas de políticas como Hillary Clinton y Margaret Wallström y el desembarco millonario de la industria humanitaria han consolidado la violencia sexual como marco de referencia a la hora de pensar y referirse a la RDCongo, hasta el punto de que «el Oriente Congoleño y la violación han quedado indefectiblemente conectados para las audiencias internacionales" (Auteserre 2012: 14).

Para algunas autoras que están haciendo un trabajo muy relevante y de gran recorrido empírico — como Severine Auteserre (2010; 2012) o Douma y Hilshorst, desde el Centro de Estudios de Catástrofes de la Universidad de Wageningen (2012, 2013, 2014)_, la "hipervisibilización" de los crímenes sexuales cometidos contra mujeres en la RDCongo tiene varias consecuencias inesperadas. En primer lugar, se ha reforzado el marco de comprensión tradicional en el que los hombres son los perpetradores de los crímenes padecidos por las mujeres, obviando el hecho de que los hombres también son víctimas de crímenes sexuales siendo, de hecho, 1 de cada 10 casos documentados (Auteserre 2012). Por otro lado, este retrato también ignora el hecho de que a pesar de que los hombres no son el principal objetivo de este tipo de crímenes, sufren más de otros abusos y torturas como participantes del conflicto armado (Koddenbrock 2012:558). Estas narrativas simplistas y abusivas, al retratar a la víctima del conflicto congoleño como "una mujer violada" ha generado un jerarquía en la victimización, invisibilizando la realidad apabullante de otras formas de victimismo en el marco del conflicto, como son: la tortura no sexual, el reclutamiento forzoso de menores y la pérdidas de familiares muertos o desaparecidos (Auteserre 2012: 4).

En segundo lugar, han proliferado los proyectos de la ayuda internacional destinados a la asistencia de víctimas mientras que sólo una parte menor de los proyectos que se ejecutan en el este de la RDC están destinados a acabar con las causas de la violencia, como son los conflictos por la tierra, las hostilidades entre civiles y militares o la desorganización de las fuerzas de seguridad. Auteserre apunta la paradoja siguiente (2012: 15): la violencia sexual ha moldeado la provisión de la atención sanitaria a mujeres, hasta el punto de que todos los hospitales tienen una sección dedicada a los casos de violencia sexual. Dada la falta de acceso a la salud de la población general, las mujeres congoleñas han aprendido que la mejor manera de tratarse médicamente de cualquier enfermedad es apelar haber sufrido un ataque sexual.

Por último, hay autores que denuncian que los fondos para la asistencia a las víctimas de violencia sexual se han convertido en negocio (fond $d u$ commerce) para muchos actores del conflicto, desde los actores armados que la usan como arma 
de negociación (Auteserre 2012) a las organizaciones locales, que se han multiplicado con el fin de acceder a los fondos millonarios que llegan para este fin. Douma y Hilhorst, exponen la necesidad de evaluar crudamente el impacto de la ayuda internacional millonaria que ha llegado para luchar contra los efectos de los crímenes sexuales, ya que hay una creciente inquietud entre los profesionales de las agencias internacionales y los actores locales acerca de la efectividad de los programas (2013: 2).

\section{LOS CUERPOS QUE HABLAN: NARRATIVAS SOBRE LA VIOLENCIA SEXUAL}

Vamos caminando en fila por un camino que se abre entre los bananos. El sol se empieza a ocultar tras los montes de Walungu. Delante de mí va Robert, camarógrafo de la BBC, lamentándose por no haber traído su cámara, al ver tanta belleza desperdiciada para sus horas de rodaje. Encabeza la marcha una joven congoleña, Mapendo, que nos lleva hasta su casa. Tras una caminata nos abrimos paso entre los bananos y llegamos a una pequeña parcela rodeada de árboles, en la que se levanta una casita de barro y paja. Nuestra llegada interrumpe a unos niños que están jugando. Una de ellas es la hija de Mapendo, una de las protagonistas de las historias que se incluirá en el documental que la cadena británica está rodando. Mapendo ha accedido a ser entrevistada y filmada por los periodistas de la BBC para el documental que estrenarán en 2010 sobre la violencia sexual en Congo. Mapendo se sienta frente a su casa y comienza a narrar su historia ante una pequeña cámara que lleva la productora. Habla con una mirada indescifrable y una voz dolorosamente dulce. Fue violada tiempo atrás por un grupo de milicianos y de aquel ataque nació su hija, la que ahora juega con los polluelos. No recuerda los detalles. Sólo recuerda que uno de los soldados le regaló un reloj antes de irse. Después de la violación no se casó; se quedó en la casa familiar y allí decidió criar a su hija. Se siente afortunada, porque no sufrió repudio por parte de su familia y recibió ayuda durante su enfermedad. Un año después, cuando caminaba con un grupo de mujeres de la aldea, fue capturada por unos hombres. Mapendo cree que eran miembros del FDLR ${ }^{8}$, por su aspecto y su forma de hablar. Las retuvieron en la selva durante días y allí fueron violadas, azotadas y torturadas. Después de varias semanas, las dejaron marchar. Volvió a su casa herida con una sola certeza: los hombres hacen daño?.

Partiendo de la idea de que la guerra transforma los cuerpos individuales en cuerpos sociales, lo que nos interesa ahora es ver qué ocurre con esos cuerpos sociales, que son individualizados en los relatos para lograr un impacto narrativo. Para Olujic, durante los años 90, varias instituciones — medios, médicos, gobiernos- manipularon las violaciones a las mujeres en Bosnia, "Convirtiendo los cuerpos individuales en cuerpos políticos, controlando y definiendo los usos políticos de las violaciones en sus relaciones con Occidente" (Olujic 1998: 46). El caso del feminicidio de la RDC, veinte años después, tiene similitudes. Este artículo se centra en los "usos políticos" de las violaciones de mujeres congoleñas por parte de actores no políticos, como son: los medios de comunicación o los activistas locales, a través de prácticas narrativas irresponsables que se sustentan en el abuso de los testimonios de víctimas y basados en la narración corporal de la aberración.

\footnotetext{
${ }^{8}$ Frente Democrático para la Liberación de Ruanda.

${ }^{8}$ Kanyola, RDCongo. 2009. Fragmentos del diario de campo, acompañando a las periodistas de AFEM-SK a recoger testimonios de víctimas
} 
Retomemos otra de las preguntas que lanzaba Chiwengo (2008: 20): “¿Cómo logran algunas narrativas de la violencia recibir la identificación, la empatía, la acción política y el compromiso de las agencias mientras otras reciben la apatía?». Para Auteserre, las respuestas a esta pregunta son varias: en primer lugar, porque encaja con los estereotipos que identifican a los congoleños como bestias salvajes y primitivas; en segundo lugar, porque resuena con las audiencias de todo el mundo, ya que la violencia sexual contra mujeres es una práctica muy extendida; y, en tercer lugar, porque esta narrativa incluye una respuesta clara al problema - proveer asistencia a las víctimas - y la posibilidad de que el público se involucre haciendo donaciones a este tipo de proyectos (2012: 14). Auteserre explora en su trabajo las ideas-fuerza sobre el conflicto y la intervención en el Congo (2010; 2012) el elemento fundamental que comparten todos los discursos: la simplicidad narrativa. La simplicidad se basa en presentar una línea argumental sin complicaciones, que utilice elementos ya conocidos para el público general y aporta una solución directa (2012: 6). Todos los actores que se encargan de elaborar los relatos sobre la violencia en el Congo precisan de la simplicidad narrativa para lograr sus objetivos: las víctimas, asistencia; los activistas, justicia; los periodistas, una buena historia, y, los humanitarios, una buena causa.

\section{El RELATO DE LAS VÍCTIMAS DE VIOLENCIA SEXUAL (2005-2015)}

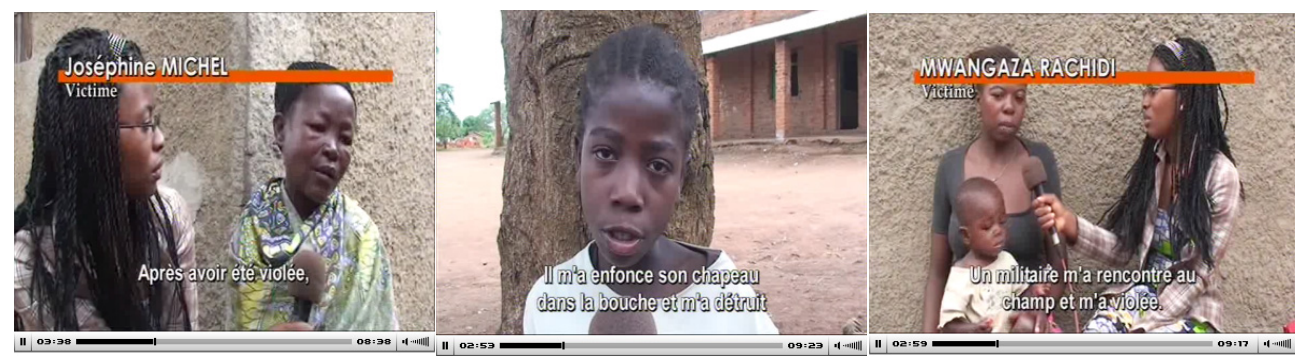

Fotogramas del documental Violencia Sexual en Sur Kivu, de AFEM-SK. Periodista con víctimas.

Observo cómo entrevista la periodista congoleña a la mujer víctima de violencia sexual. Se sienta a su lado, casi pegada a ella. Le hace las preguntas sin apenas mirarla, en voz muy baja y utilizando la lengua tribal. Las preguntas son cortas y no suele terminarlas, de tal manera que la víctima, como cogiéndolas al vuelo, acaba las preguntas y elabora la respuesta a continuación. La periodista mira a la mujer víctima de vez en cuando y va lanzando pequeñas voces, muy guturales, que funcionan a modo de afirmación. Esta forma de afirmar es bastante habitual en las conversaciones de los congoleños de esta zona, que están pobladas por silencios largos, a veces interrumpidos por repentinos golpes de voz. El contacto físico, el silencio y la paciencia son las pautas que permiten a las periodistas congoleñas guiar a las víctimas a través de su testimonio, doloroso y difícil de verbalizar. Algunas, más temperamentales y expresivas, gesticulan más cuando recogen los materiales sonoros o cuando preguntan a las víctimas, pero siempre se limitan a afirmar con la cabeza, a escuchar en silencio y a expresar, muy sutilmente, con el rostro, una cierta empatía con el dolor que las víctimas van describiendo?.

\footnotetext{
${ }^{10}$ Kanyola, RDCongo. 2009. Diario de campo
} 
Como un canto, al son de las manos palmeando para dar ritmo a una narración que parece venir de lejos, nos van llegando las historias de sufrimiento de las víctimas. Las mujeres congoleñas que han vivido los crímenes sexuales, como ocurre con tantas otras víctimas de catástrofes y de violencia, están acostumbradas a hablar de los ataques con periodistas, personal humanitario, médicos, asistentes sociales y psicólogos. Cada cual pide un tipo de relato. Para las víctimas, la narración del abuso tiene un fin eminentemente terapéutico, es el primer paso para iniciar la sanación. Cuando llevé a cabo el trabajo etnográfico en la RDCongo, en un contexto descarnado y urgente, me di cuenta de que un gran impedimento para la sanación, es que el dolor es una experiencia radicalmente privada caracterizada por "su incompartibilidad" (Scarry 1985: 4). Sin embargo, es sugerente tener en cuenta que el dolor, como el miedo, el asco y la abyección, gritados o susurrados, se calman cuando se narran encadenados en la historia (Kristeva 1988: 192), lo que está en la base de la acción del testimonio.

En el trabajo de campo, una de mis tareas fue reconstruir las rutinas profesionales de las periodistas congoleñas que denuncian el feminicidio. Uno de los lugares a los que viajan en repetidas ocasiones para recoger testimonios de víctimas son los llamados "centros de tránsito", como el que describo, ubicado en Kanyola (en el territorio de Walungu). Los "centros de tránsito" son pequeños terrenos de las comunidades o adquiridos por asociaciones locales con el fin de dar asistencia a las víctimas de violencia sexual. En ellos, hay pequeñas edificaciones que pueden albergar a las víctimas que no puedan retornar a sus hogares y terrenos comunitarios en los que los terapeutas trabajan con las víctimas. Todas ellas han sido tratadas por los médicos y están en fase de curación, pero atienden a los centros de tránsito para hacer talleres de formación o recibir asistencia psicológica. En muchas ocasiones, estos centros funcionan también como gabinetes de asistencia legal, es decir, apoyan a las víctimas para que denuncien los crímenes. El día a día de los centros se traduce en la convivencia de decenas de mujeres que, a pesar de estar en estadios diferentes del proceso de recuperación, tienen necesidad de contar y entender lo ocurrido. Allí se vive, como de costumbre en esta región del Congo, lentamente y en comunidad. Se habla poco, y se escucha mucho; se canta poco, y se espera mucho.

En los centros de tránsito de víctimas de la RDCongo, se han generado durante años espacios que reúnen las condiciones de tiempo, respeto y seguridad para crear una comunidad de testimonio. Pese a que el fin de los centros de tránsito es dar asistencia psico-social a las víctimas de crímenes sexuales, uno de los resultados es precisamente la aparición de estas comunidades de testimonio, basadas en la necesidad de superar la vergüenza moral y la culpa. La comunidad se basa en el silencio y el testimonio, que es el producto de la necesidad de la víctima de atravesar la abyección, siendo el dolor el aspecto íntimo y el horror el rostro público (Kristeva 1988: 185). Fassin (2007: 175) nos dice que: "el cuerpo es una presencia en uno mismo y en el Mundo, incrustado en una historia que es a la vez individual y colectiva". Esta afirmación explica claramente la doble dimensión de la experiencia de la violencia, a la vez individual, pero a la vez compartida, tanto para la sanción como para el ataque y el repudio. La vida comunitaria en espacios de noviolencia sirve a las mujeres para liberarse, restaurarles la creencia en sí mismas, en su autoridad para determinar 
qué es real y cómo debe ser contado. El paso más fundamental, pese a la aparente nimiedad, es la asunción de que la deshumanización no se verifica sólo en aquellos que fueron despojados de su humanidad, sino también en los que la despojaron (Freire 1970: 38). Las mujeres, mediante el testimonio, el visionado de películas, la terapia o los cantos, dejan de ser seres duales, puesto que dejan de alojar al opresor en sí mismas (Freire 1970: 41).

Francisco Ferrándiz, al hablar de la grabación de las exhumaciones de las fosas comunes que dejan al descubierto los restos humanos (2008, 2010, 2013), concluye que este tipo de imágenes se han convertido en signos incuestionables de las violaciones de derechos humanos. Afirma "que se han convertido en metáforas, puntos éticos de referencia, iconos seculares cuyo barniz intensamente simbólico recubre su información referencial" (Ferrándiz 2008: 4), de la misma manera en que lo han hecho los cuerpos violados de las mujeres congoleñas. Existe un potente paralelismo entre las fosas comunes abiertas para reivindicar crímenes pasados y reparaciones presentes y los cuerpos expuestos de las víctimas que recuerdan. Ferrándiz dice que las fosas con sus cadáveres sociales tienen "poder iconográfico y potencial visual de transgresión", que pueden revertir "las políticas de invisibilización de las víctimas adaptándose a las necesidades de los medios contemporáneos con extrema eficiencia y poesía" (Ferrándiz 2008: 5). Así, los cuerpos violados de las mujeres congoleñas también se han convertido en signos de la violencia perpetrada, con intenso poder transgresor a nivel visual y mediático. Los cadáveres de los hombres congoleños han fracasado a la hora de "hablar" sobre las guerras de la RDCongo, porque los muertos guardan silencio; sin embargo, los cuerpos de las mujeres violadas están vivos, y "son cuerpos que recuerdan" (Fassin 2007: xvi).

Las mujeres congoleñas violadas y torturadas se han convertido en las metáforas del trauma congoleño del siglo XXI, de la misma manera que los cuerpos mutilados retratados por Seeley Harris eran el resumen del horror del Congo de la era del caucho. Es un trauma, "esa impronta colectiva registrada en un grupo ante una exposición histórica pasada" (Fassin y Rechtman 2009: xi) que se revela en los cuerpos, pero se presupone en la psique, de tal manera que los cuerpos se han convertido en cuerpos que hablan, los signos más eficientes para narrar la violación de derechos humanos en plena era del "imperio del trauma" (Fassin y Rechtman 2009). Para narrar de forma elocuente, hay una escenografía y un guión concretos. El guión se construye a partir de la alusión a la destrucción de los cuerpos, al uso de primeros planos y a la puesta en escena que usa elementos que hacen referencia directa a la pobreza, la indefensión y la necesidad de ayuda de las víctimas: la presencia de las mujeres, su vestimenta, la tierra roja, las tiendas del ACNUR, las casa de barro y paja, la mirada perdida.

La necesidad que tienen las víctimas de narrar para sanar puede ser utilizada por quienes están fuera de la comunidad de testimonio, como son los buscadores de historias y de poder. Éstos, al no ser capaces de dilucidar el dolor, ese aspecto íntimo de la violencia, utilizarán el horror para conmover. El tipo de historias que pueden encontrar los humanitarios, los periodistas o los activistas en estos centros de tránsito, o en otras comunidades de testimonio, encaja con la narrativa que parte de la metáfora del "África infantil", una maniobra retórica que proyecta a los africanos como víctimas feminizadas y necesitadas de ayuda (Dunn 2003: 29-30) y genera sentimien- 
tos de paternalismo y ternura. Una de las grandes construcciones sociales en torno al trauma es la pasividad asociada a todos los agentes sociales que tienen la etiqueta de "traumatizados", por lo que el trabajo que tenemos como científicos sociales, en este caso, "es desnaturalizar el trauma y repolitizar a las víctimas" (Fassin y Rechtman 2009: xii).

\section{Relatos ACTIVISTAS: POUR QUOI? (2009)}

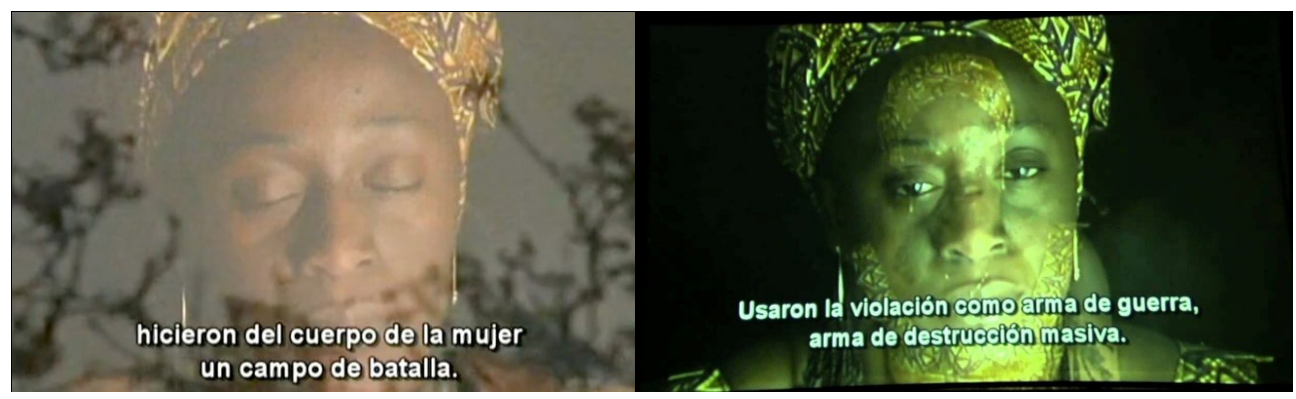

Fotogramas del filme Pour Quoi? (Ouka Leele 2009)

¿Durante cuánto tiempo vamos a seguir insensibles al dolor de las mujeres violadas en la República Democrática del Congo? Las mujeres congoleñas heridas en cuerpo y alma, reclaman justicia y reparación. Es justo y necesario que todos aquellos que financian y alimentan este horror por razones económicas respondan de sus actos. España, uno de los pocos países europeos que ha vivido los horrores de la dictadura en un pasado reciente y que ha logrado construir en tan poco tiempo un país de derechos humanos, en el que los derechos de las mujeres son respetados a escala nacional e internacional, un remanso de paz, un país de justicia... sabrá intervenir con todo su peso ante la comunidad internacional en favor de esas mujeres congoleñas que sólo piden poder vivir en paz en su país y satisfacer las necesidades de sus hijos. (...) El prestigioso Premio Príncipe de Asturias de la Concordia 2014 con el que nos han honrado, es para nosotros una gran oportunidad de difundir aún con más fuerza y proyección nuestros mensajes de sensibilización, nuestras reivindicaciones y nuestras alegaciones. Este premio servirá de altavoz para la defensa de la causa de las mujeres violadas en el mundo en general y en particular en la República Democrática del Congo. Por ello queremos dar las gracias muy sinceramente: a la Corona de España por haber instaurado este Premio Príncipe de Asturias, a los miembros del jurado por haber confiado en nuestra causa, a las organizaciones que han presentado nuestra candidatura a este galardón, a las Organizaciones de la sociedad civil española que nos han apoyado y acompañado en nuestra sensibilización a nivel internacional. ${ }^{11}$

Caddy Adzuba, como las demás periodistas de la región de los Kivus, ha comprendido la relevancia de acceder a los espacios transnacionales para denunciar el feminicidio congoleño y transformar la política doméstica (García-Mingo 2013). Por ese motivo, accedió a protagonizar Pour Quoi?, un film corto de vídeo-arte pro-

\footnotetext{
${ }^{11}$ Fragmento del discurso de Caddy Adzuba en la ceremonia de entrega de los Premios Príncipe de Asturias 2014
} 
ducido por las españolas Ouka Leele y Bettina Caparrós. Esta obra se basa en el testimonio de Caddy, que a su vez recoge testimonios de víctimas, resultando en un meta-relato abstracto y descontextualizado, apoyado en el poder narrativo del cuerpo hablando sobre los cuerpos destruidos. Las organizaciones locales congoleñas utilizan los testimonios de las víctimas de violencia sexual para articular una denuncia más amplia que incluye: los abusos de los derechos de la infancia, la inseguridad de la población civil, la explotación ilegal de los recursos naturales y la exigencia del fin de la acción violenta de los grupos armados. A su vez, muchas de las víctimas de violencia sexual se han convertido en activistas que nutren voluntariamente este activismo global. Es importante no obviar la dimensión activista de las víctimas, ya que estaríamos reproduciendo "las peores prácticas masculinas que sitúan a las mujeres en el lugar de las carencias simbólicas" (Magallón 2006: 41).

Las activistas pro-derechos congoleñas viven en un mundo que ha sido muy mitificado en la esfera internacional contemporánea: viven en "la capital mundial de la violación" (Auteserre 2012). Ellas lo saben y hacen una gestión estratégica de la diferencia - usando lenguajes, atuendos, eslóganes- para lograr una serie de fines políticos. Este hecho no está libre de contradicciones, puesto que este tipo de prácticas confía en imágenes esencializadas de la diferencia (McLagan 2002: 91) y la comprensión simplista de lo que es una mujer, una víctima o un perpetrador. Las activistas congoleñas, como Caddy Adzuba, son perfectamente conscientes de estos riesgos, pero asumen que es mejor correrlos que dejar la situación como está. De mi trabajo etnográfico se desprende que las activistas conocen bien los públicos locales y globales, de tal manera que "ordenan los relatos que tienen de sí mismas, de sus logros y de los temas que les interesan" (McLagan 2002: 92) para dar a las audiencias, periodistas, donantes y a Sus Majestades exactamente lo que quieren. Esta objetivizacion estratégica de la cultura y del dolor encaja en el concepto de "activismo cultural" (Ginsburg 2002: 9) que hace referencia a la gestión de la auto-representación con fines políticos que demuestra que las mujeres congoleñas hacen una mediación y movilización consciente de la cultura (Ginsburg et al. 2002: 8).

Con el fin de movilizar a las masas para que apoyen el cumplimiento de los derechos humanos, las activistas, como se puede ver en el discurso, se basan en una suerte de moral transnacional y usan unos discursos difusos que apelan a la empatía y a la solidaridad (Gregory 2006: 195). Buscan "movilizar la vergüenza", por eso no importa lo sofisticada o simple que sea la campaña, la estrategia dominante de sus acciones es "convertir la rabia en acción" (Avni 2006: 205). El activismo pro derechos humanos ha proporcionado a víctimas y testigos el derecho a protestar frente al abuso dentro y fuera de sus fronteras. Se ha basado en los relatos de las historias de vida, que aportan particularidad a la experiencia masiva del sufrimiento de la población, como una referencia a otros problemas mayores (Gregory 2006: 203). La traducción de los problemas de fondo a testimonios "que conforman collage de verdades que perturben y motiven reacciones" (Redfield 2006: 12) ha privilegiado el uso del vídeo y la fotografía en este tipo de campañas. Por otro lado, los testimonios han capitalizado los cuerpos como principales dispositivos narrativos para hablar de la violencia, dada la importancia de los cuerpos en estas violencias y dada la capacidad de los cuerpos para hablar de los ataques con eficiencia: mediante el lenguaje de la 
enfermedad, a través del rastro de las lesiones físicas y gracias a la expresividad del dolor.

Los activistas pro-derechos humanos se enfrentan al desafío de hacer visible y entendible el sufrimiento, para ello, tienden a objetivar verbalmente el dolor a través de sus características en referentes al cuerpo humano (Chiwengo 2008: 18), lo que otorga al cuerpo una importancia sin precedentes. De la eficiencia de las imágenes en relación al cuerpo depende que se transmita el dolor; y, debido a que la narración del sufrimiento de los cuerpos congoleños está dirigido a audiencias occidentales, "el discurso humanitario debe estar empaquetado de acuerdo con los estándares del público objetivo" (Chiwengo 2008: 31). Este hecho explica que se recurra constantemente al lenguaje medicalizado y burocratizado, que incluye términos médicos y legales, como: "crímenes de lesa humanidad o fístula traumática". Es claro que el uso del testimonio y de las experiencias de los locales ha resultado positivo para la activista congoleña, visto "el éxito" de la campaña activista de Caddy Adzuba y el reconocimiento que ha recibido mediante el galardón español, pero la sobreabundancia de testimonios circulando corre el riesgo constante de producir "una economía del sufrimiento estratificada y massmediatizada en la que la calidad de víctima es reificada y fetichizada" (McLagan 2006: 194).

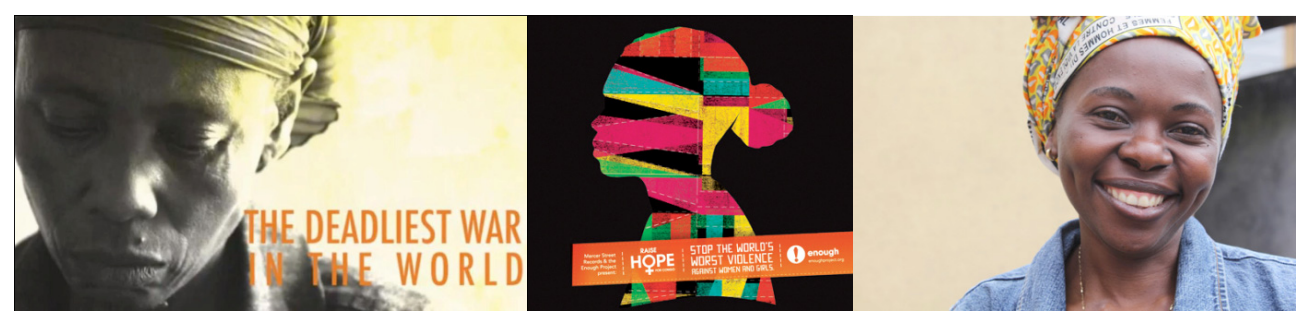

Materiales de campaña de la ONG estadounidense Enough Project

Desde hace años, en el Kivu las violencias sexuales son el foco de atención de la industria de ayuda, lo que se ha traducido en: la llegada de fondos de la ayuda multilateral, la afluencia de agencias donantes de la ayuda, el establecimiento de secciones y la aparición de programas especializados dentro de las agencias de la ONU. Han proliferado pequeñas organizaciones internacionales y locales en terreno dedicadas a este tema y se han multiplicado de visitas de popes de la ayuda, estrellas de cine, periodistas y políticos planetarios. La llegada de miles de millones ${ }^{12}$ de dólares para la lucha contra la violencia sexual ha supuesto un impacto en la región sólo comparable a la colonización, tanto por su despliegue ideológico y de representación,

${ }^{12}$ Sólo uno de los programas de atención a víctimas de la violencia sexual del Hospital de Panzi recibe 1 millón de USD al año, según datos recogidos en entrevistas a personal del hospital durante el trabajo de campo conducido en RDCongo en 2009 
como por el desbarajuste económico que supone la ayuda masiva y descontrolada con el consiguiente debilitamiento de la clase política y de la sociedad. Respecto a la pertinencia de la ayuda en la RDCongo, Gerard Prunier asegura que la colección de intervenciones ha sido en muchas ocasiones la mejor opción para los actores internacionales porque genera muchos réditos para la comunidad internacional: le permite hacer lo que mejor sabe hacer; es más barato que cualquier implicación militar más permanente; es más fácil de consensuar, más "neutral» y exenta de valores; es más visible para los medios y provee a la opinión pública mundial una alternativa lowcost a la acción política real (2009: 347).

El humanitarianismo se ha convertido en un lenguaje político que estructura nuestra comprensión del mundo y conforma la política contemporánea (Koddenbrock 2012b:517). Para ello, el humanitarismo confía en un discurso emocional, y la espectacularización del sufrimiento, basado en «un lenguaje común respecto a la aprehensión por las vidas humanas y por el sufrimiento. Los eslóganes sobre el bien y el mal ahora encuentran su medida en los recuentos de cuerpos caídos y el real o potencial daño que puedan sufrir las personas comunes. La sensibilidad humanitaria está definiendo el modo adecuado que debe tomar la conducta política y sugiere un límite para ésta (Redfield 2014: 542).

Por otro lado, las organizaciones humanitarias han llegado a desarrollar campañas muy sofisticadas, convirtiéndose en un nuevo tipo de productores de contenidos mediáticos, lo que ha generado una "mediatización de la ayuda" (Gregory 2006: 197). Este hecho ha promovido la aparición de grandes campañas sobre catástrofes planetarias, conflictos olvidados y agujeros negros del mundo que tienen la capacidad de aupar a las causas de moda (McLagan 2002: 91) mediante estrategias comunicativas como la organización de macro eventos de entretenimiento o la incorporación a la lucha por la causa de personalidades famosas (celebrity interest) (McLagan 2002: 94). La naturaleza de los medios de comunicación, la sensibilidad de los públicos y las habilidades de algunos activistas han hecho que "algunos cadáveres sean más sexys para los medios que otros" (Prunier 2009: 353). Kevin Rozario afirma que en la medida en que las organizaciones humanitarias están totalmente implicadas en la era del consumo, se han trasladado del reino de lo moral para instalarse en "mundo de los sueños del consumo masivo", convirtiendo así a la filantropía en sí misma en una actividad consumista (2003: 429), lo que ha introducido a la empresa humanitaria en la órbita del entretenimiento. Ha quedado demostrado que la violencia sexual de RDCongo tiene un alto valor mediático para activistas y agencias, que "han logrado una atención sin precedentes cuando hablan sobre algo tan abominable como la "epidemia de violaciones" (Koddenbrock 2012:552). Este es el caso de Enough Project, un ejemplo paradigmático de organización no gubernamental volcada en el caso de la RDC para lograr visibilidad en su lugar de origen, para lo cual ha utilizado incesantemente el recurso del testimonio, el victimismo y las contrapartes locales atractivas.

En este marco, la habilidad para poner rostro al sufrimiento sigue siendo la manera más poderosa de conmover a espectadores y lectores (Rozario 2003:441), lo que explica la emergencia de estrellas locales de la ayuda y del activismo, como son Caddy Adzuba o el Doctor Mukwege, el ginecólogo del Hospital de Panzi, Premio Sajarov 2014. A su vez, el humanitarismo transnacional necesita dramatizar o sensacionalizar el sufrimiento, para lo cual hay que poner cuerpos a las causas y a causas violentas, 
pero no cualquier cuerpo: los cuerpos violentados. El tipo de textos que producen las campañas massmediáticas de la ayuda es lo que Rozario llama "espectáculos del sufrimiento" (2003: 432), ya que para este autor, "la solidaridad no puede existir sin un cierto regusto por los espectáculos del sufrimiento" (2003: 441). De esta manera, las demandas de derechos son hechas a través del idioma del sufrimiento y tienden a reificarlo en una forma testimonial, como historias tristes y sentimentales (McLagan 2006: 193). A lo largo del tiempo, las convenciones de la representación de la narrativa testimonial han emergido, y han pivotado sobre la presentación de los cuerpos de las víctimas, las cuales obtienen la simpatía de las audiencias (McLagan 2006: 193). En Congo, según explica Hunt, hay ya una tradición de "uso de cifras y fotos chocantes para producir repulsión y lastima entre los espectadores y generar fondos humanitarios" (Hunt 2008: 238).

Toda esta tradición ha provocado la aparición de dos inconvenientes: primero, que se está produciendo una "apropiación del sufrimiento" (Kleinman y Kleinman 1997 en Gregory, 2006); y segundo, se está generando una deshistorización y descontextualización de los fenómenos, que son aislados y reinsertados en la realidad creada por las prácticas industriales de la ayuda internacional. En relación a cómo fueron representados los crímenes de Leopoldo II en la que fue la primera campaña humanitaria global, Hunt afirma que "en muchas ocasiones, los individuos no eran nombrados con sus nombres y apellidos en las capturas y sus historias fueron desapareciendo". Es como si los espectadores humanitarios ya conocieran a los protagonistas y sus historias. La cantidad y la simultaneidad de las imágenes resume todo lo que necesitan saber: el horror".

RELATOS MEDiÁticos: "LA GUERRA CONTRA LAS MUJERES” (HERNÁN ZiN 2013)
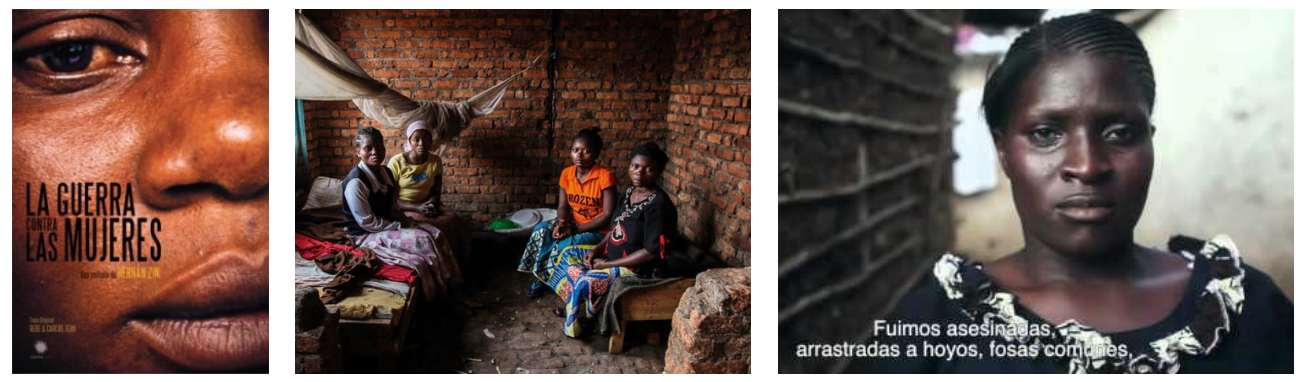

Fotogramas del filme documental de Hernán Zin (2013)

Olujic reivindicó en 1995 que "las historias de violaciones de mujeres están de moda" (1995: 199), lo que quiere decir que son ya veinte años de tradición discursiva sobre las "mujeres violadas". En la RDCongo, sin embargo, la violencia sexual no ha dominado el discurso hasta pasado el año 2000, a raíz de la publicación del informe de Human Rights Watch denominado: "La guerra dentro de la guerra". Desde entonces, los periodistas y, sobre todo, los jefes de redacción han favorecido de manera cre- 
ciente el enfoque del feminicidio al referirse al conflicto (Auteserre 2012: 13), casi o tanto más que mediante el dispositivo explicativo y de denuncia de "la maldición del coltan" o el "coltan ensangrentado".

La Guerra contra las Mujeres (2013) es un film documental del corresponsal de guerra argentino Hernán Zin, que pretende retratar las vidas de las mujeres que han padecido crímenes sexuales. El planteamiento dramático del documental es el siguiente: se aborda el problema de la violencia sexual en varios países del mundo, poniendo especial atención en el feminicidio de la RDCongo. El hilo conductor de la historia es una mujer, víctima de violencia sexual, que se somete en repetidas ocasiones a operaciones quirúrgicas en el archiconocido Hospital de Panzi (Bukavu, Sur Kivu), para que le reconstruyan su aparato reproductor, dañado en una brutal violación años atrás. La protagonista del documental ya se ha sometido a seis operaciones, pero aún quedan por lo menos dos, dando cuenta así del impacto de la violencia sobre las vidas de estas mujeres. La narración de la superación de las dificultades, su vida en el barrio y la curación final de las heridas se va entretejiendo con otras historias de víctimas de la violencia sexual en otros países y contextos, generando así una colección de carencias narrativas que enganchan y comprometen al espectador que esperará hasta el final, el momento en que la víctima salga "triunfal" del quirófano tras la última operación.

A pesar de los francos intentos del corresponsal de explotar los medios de comunicación para lograr que pase su mensaje (una información hallada con dificultad y tan urgente que siente la obligación de transmitir) sus textos acaban siendo sospechosos de pertenecer "a la cultura de masas que convierte el horror y la tragedia en estremecimiento barato" (Rozario 2003: 420). Algunos periodistas occidentales, que sobrepasando impedimentos organizacionales y todo tipo de dificultades, llegan a la RDCongo para contar "la verdadera historia" pero, lamentablemente, en la mayoría de los casos acaban haciendo la representación tradicional de los conflictos africanos, "primitivos" y "brutales". Así, acaba reforzando los prejuicios existentes y limita las posibilidades de profundizar en las causas o consecuencias (Aguirre et al. 2002: 31).

En términos de conflictos armados, colapso económico-político, sufrimiento humano y expolio de la naturaleza, África lidera todas las estadísticas de la segunda mitad del siglo XX y de lo que llevamos de siglo XXI. Desde 1970 hasta la actualidad se han producido más de treinta guerras, cobrándose más de la mitad de las bajas mundiales, en su mayoría víctimas civiles; además, se prodiga la centralización del poder en pocas manos, la corrupción, el despotismo, la persecución de minorías y pueblos indígenas, la falta de representación del pueblo (Aguirre et al. 2002: 145), la impunidad de los crímenes, la violación sistemática de derechos humanos y la migración masiva de la población. África motiva una profunda "fatiga de la compasión" (Moeller 1999) en un público que presencia, una y otra vez, conflictos, epidemias y hambrunas naturalizados, es decir, representados y entendidos como catástrofes naturales: inexplicables, repentinos, aleatorios, inevitables e irresolubles.

Por motivos varios, tales como las imposiciones de las transnacionales mediáticas o las convenciones profesionales, los periodistas tienden a dar explicaciones incompletas, fragmentadas e incluso erróneas de la violencia, "la cual es descrita como si hubiera sido causada por las mismas fuerzas estocásticas que causan los terremotos, las inundaciones y los huracanes" (Pedelty 1995: 24). La violencia es para los perio- 
distas una suerte de "trampa mortal profesional", que ejerce gran atracción sobre ellos, que "como el Marlow de Conrad confían en poder dar un día a sus lectores una mirada sobre el mismísimo corazón de las tinieblas" (Pedelty 1995: 23) pero es, salvo raras excepciones, un objeto de escrutinio imposible. A la postre una noticia plagada de sombras y aristas, por ser como es la violencia un fenómeno estructurado en capas intrincadas (Nordstrom y Robben 1995: 5). Los profesionales de los medios, conscientes de la fatiga de la compasión que tienen sus espectadores, intentan encontrar siempre pedazos sensacionales de historias que retengan la atención de sus audiencias (Moeller 1999: 2). Es así como llegan las terribles historias de supervivencia de las mujeres congoleñas a los espectadores españoles, simplificadas y descontextualizadas. El único beneficiado de la emisión de la pieza es el periodista y su medio, por lo que estas mujeres, consintiendo participar en la actual popular cobertura de violaciones están "Volviendo a ser violadas" (Olujic 1995: 197).

\section{CONCLUSIONES: CUERPOS QUE RECUERDAN, CUERPOS QUE RESISTEN}

No es secreto para nadie. Varios informes de Organizaciones No Gubernamentales internacionales y de expertos de las Naciones Unidas han denunciado la masacre organizada y planificada en el este de la República Democrática del Congo. Los diversos encuentros de paz y acuerdos firmados por el gobierno congoleño y los beligerantes nos llevaron a confiar en un final inminente del conflicto. Pero, lamentablemente, las mujeres siguen siendo violadas, los niños siguen siendo reclutados a la fuerza en los grupos armados, las familias siguen errando por los caminos del exilio, aldeas enteras siguen siendo incendiadas, los bienes de la población siguen siendo saqueados. No, nuestra guerra no ha terminado. Estamos en guerra. Una guerra que, intencionadamente, se ha relegado en el olvido. Ante esta situación, nos tenemos que preguntar: ¿Por qué esta guerra? ¿Por qué tanto sufrimiento para las mujeres violadas? La paz y la dignidad humana, ¿son un lujo para las mujeres pobres? ¿Están condenadas a sufrir los horrores de una guerra que no han planificado? Permítanme pedir cuentas a ciertas empresas multinacionales que, en busca de sus propios intereses, han contribuido a asolar a sangre y fuego este gran y hermoso país de Congo, arrebatándoles la vida a más de 6 millones de personas y su dignidad y su honor a más de 500.000 mujeres violadas ${ }^{13}$.

Caddy sabe que si quiere conseguir visibilidad para "su causa", debe acceder a los espacios globales y seguir la lógica del humanitarismo transnacional, lo que implica que debe adaptar sus actuaciones para que éstas sean leídas con significación política dentro de los marcos occidentales (McLagan 2002: 106). Este hecho explica sus esfuerzos para contextualizar la dimensión de su lucha explicando cuál es la situación de la mujer en su país o la tendencia a utilizar palabras, eslóganes y conceptos de moda. A la vez, vestida en pagne, da cuenta de un sutil y magnífico activismo cultural, reforzado, rearticulado y transformado gracias al uso de las nuevas técnicas de representación, de difusión y de recepción (Turner 2002: 80). Esta noche capitaliza el escenario para convertirse en "la voz local privilegiada", para encajar dentro del "imaginario de los activistas" (Ginsburg et al. 2002: 8). Sabe cuál es la representación de sí misma que ha de poner en juego en los diferentes espacios de activismo. Sabe

\footnotetext{
${ }^{13}$ Fragmento del discurso de Caddy Adzuba en la ceremonia de entrega de los Premios Príncipe de Asturias 2014
} 
que son ocasiones que no pueden perder, el Rey y la Reina de España, asisten horrorizados y emocionados, al espectáculo del activismo. Son sólo 9 minutos y Caddy los utiliza volviendo sobre las mujeres congoleñas, violadas y violentadas. No hay otra posibilidad, es el único lenguaje que se entiende internacionalmente.

Caddy representa, con su propia biografía, a los cuerpos que recuerdan, pero también a los cuerpos que resisten. Caddy representa la supervivencia en el sentido que le da Didier Fassin, al decir que "la supervivencia es la vida más allá de la vida, más vida que la vida (...) no es sólo continuar viviendo, sino vivir más intensamente" (2007: 261). Cientos, miles, cientos de miles de mujeres congoleñas son supervivientes de ataques que se han inscrito sobre sus cuerpos con un lenguaje político, impactando en sus vidas cotidianas. Sin embargo, ellas, como supervivientes, viven intensamente, también se organizan y articulan su lucha en torno a sus cuerpos diezmados. Según nos recuerda Esteban, "lejos de contemplar el cuerpo en términos pasivos, no culturales, ahistóricos, éste es visto como el lugar de resistencia, de la contestación, en diferentes contiendas económicas, sexuales, estéticas e intelectuales" (2004: 38). En muchos casos, las mujeres congoleñas toman orgullosamente sus cuerpos marcados y los arrojan a plena luz del día para transformar los mensajes inscritos sobre sus cuerpos, de vergüenza y destrucción. Se han percatado de que el cuerpo femenino no es sólo un lugar de control social (Bordo 2005 (1993): 39) sino también de resistencia y contestación. Este cambio, ayudado por el acompañamiento de mujeres ya conocedoras de este poder, ha permitido que la resistencia se torne posible y que los espacios inhóspitos de sus cuerpos puedan convertirse en puntos focales de resistencia. Un ejemplo de esto es la historia de Mama Jeanne Banyere, la directora de la Federación de las Mujeres Protestantes de Goma, que cuenta cómo, en 2003, un grupo nutrido de mujeres se lanzaron desnudas a las calles de Goma y desafiaron a cientos de hombres gritando: "iSi vais a violarnos, hacedlo ahora, porque esto tiene que acabar hoy" (Wax 2004: 181).

Más allá de las narrativas mediáticas, activistas o humanitarias, necesitamos recuperar las voces de las congoleñas, en ocasiones imposibles de escuchar entre el ruido de las campañas humanitarias. Necesitamos más voces militantes de mujeres congoleñas que han sobrevivido a la guerra, que han sido violadas, que han formado ONGs críticas con la cuestión de género, centradas en la promoción de la paz, madres activistas que estén dispuestas a partir de cero y volver a construir hogares en los que formar a sus hijos e hijas (Hunt 2008: 242). Las mujeres africanas tienen aspiraciones más allá de asegurarse la supervivencia cotidiana, tienen deseos de supervivencia real, tienen deseos de cambio político, económico, social, intelectual, profesional y personal. Las relaciones de género están transformándose rápidamente en Este del Congo, pero en ocasiones, con nuestros relatos sobre sus vidas, no estamos dando cuenta de este hecho. Al representar a las mujeres congoleñas como víctimas, las estamos atrapando simbólicamente en esa condición.

No podemos olvidar que las historias corporales del sufrimiento social que elaboramos y difundimos tienen un impacto en las comunidades que lo experimentan. Los discursos y la colección de imágenes del horror que han circulado sobre Congo han moldeado las políticas internacionales en torno al país africano. Hemos visto que representar la RDCongo como un "Corazón de las tinieblas" primitivo y oscuro tiene un correlato político y unas implicaciones a largo plazo (Dunn 2003: 173). Este artículo 
pretende ser una voz alternativa que concibe a las mujeres congoleñas como actoras de cambio y no como meros cuerpos violables y un recordatorio de que los que observamos y exponemos las miserias del mundo tenemos la obligación de "reflexionar críticamente sobre del impacto de las durísimas imágenes del sufrimiento humano que facilitamos al público" (Scheper-Hughes 1995: 416).

\section{BIBLIOGRAFÍA CITADA}

Aguirre, M. y F. Ferrándiz (eds.). 2002. The Emotion and the truth: Studies in Mass Communication and Conflict. Bilbao: Universidad de Deusto.

Amnistía Internacional. 2004. Vidas rotas. Crímenes contra mujeres en situaciones de conflicto. Madrid: EDAI.

Autesserre, S. 2012. "Dangerous tales: Dominant narratives on the Congo and their unintended consequences". African Affairs 111 (443): 202-222.

Avni, R. 2006. "Mobilizing hope: beyond the shame-based model in the Israeli-Palestinian conflict". American Anthropologist 108 (1): 205-214.

Boyla, B. 2005. La Profanation des vagins. Le viol, arme de destruction massive. Kinshasa: Le Serpent à Plumes.

Bordo, S. 2003 [1995]. Unbearable weight. Los Angeles: University of California Press.

Chiwengo, N. 2008. "When Wounds and Corpses Fail to Speak: Narratives of Violence and Rape in Congo". Comparative Studies of South Asia, Africa and the Middle East 28 (1): 78-92.

Douma, N. y D. Hilshorst. 2012 "Fond de Commerce?: Sexual Violence Assistance in the Democratic Republic of Congo". Disaster Studies, vol. 2. Wageningen: Wageningen University.

Dunn, K.C. 2003. Imagining the Congo: The international relations of identity. New York: Palgrave Macmillan.

Erikssen Baaz, M. E. y M. Stern. 2008. "Making sense of violence: Voices of soldiers in the Congo (DRC). Journal of Modern African Studies 46 (1): 57-86.

Erikssen Baaz, M. E. y M. Stern. 2009. "Why Do Soldiers Rape? Masculinity, Violence, and Sexuality in the Armed Forces in the Congo". International Studies Quarterly 53 (2): 495-518.

Escobar, A. 1995. Encountering Development: The Making and Unmaking of the Third World. Princeton: Princeton University Press.

Esteban, M. 2004. Antropología del cuerpo. Género, itinerarios corporales, identidad y cambio. Barcelona: Bellaterra.

Fassin, D. 2010. 'Heart of Humaneness: The Moral Economy of Humanitarian Intervention', en D. Fassin and M. Pandolfi (eds.), Contemporary states of emergency. The politics of military and humanitarian interventions, 269-93. Brooklyn: Zone Books.

Fassin, D. y R. Rechtman. 2009. The empire of trauma: An inquiry into the condition of victimbood. Princeton: Princeton University Press.

Feldman, A. 1991. Formations of Violence: The narrative of the body and political terror in Northern Ireland.Chicago: University of Chicago Press.

Ferrándiz, F. 2008. La etnografía como campo de minas: de las violencias cotidianas a los paisajes posbélicos, en XI Congreso de Antropología: Retos teóricos y Nuevas prácticas: 89-115. Donostia: Ankulegi Antropologia Elkartea.

Freire, P. 1970. Pedagogía del Oprimido. Montevideo: Tierra Nueva.

García-Mingo, E. 2013. "Políticas de activismo mediático en Sur Kivu (R.D. Congo): Mujeres activistas y su uso de blogs, Youtube y Flickr en la Construcción de Paz". Tejuelo 8: 124-144.

Ginsburg, F. 2002. Mediating Culture: Indigenous Media, Ethnographic Film, and the Production of Identity, en K. Askew y R. Wilks, The Anthropology of Media: A Reader: 211-238. Londres: Blackwell.

Ginsburg, F., L. Abu-Lughod y B. Larkin. 2002. Media Worlds. Antropology on a new terrain. Los Angeles: University of California Press.

Gregory, S. 2006. "Transnational Storytelling: Human Rights, WITNESS, and Video Advocacy". American Anthropologist 108 (1): 195-204.

Grosz, E. 1994. Volatile bodies. Towards a corporeal feminism. Bloomington: Indiana University Press. 
Human Rights Watch. 2002. The War within the War. Sexual violence against women and girls in Eastern Congo. Nueva York: Human Rights Watch.

Human Rights Watch. 2009. Les soldats violent, les comandants ferment les yeux. Violences sexuelles et réforme militaire en République démocratique du Congo. Nueva York: Human Rights Watch.

Hunt, N. 2008. "An acoustic register, tenacious images, and Congolese scenes of rape and repetition". Cultural Antbropology 22 (2), 220-253.

International Rescue Comittee. 2008. Mortality in the DRC: an ongoing crisis. Nueva York: IRC.

Kristeva, J. 1988. Poderes de la perversión. Buenos Aires: Catálogos.

Koddenbrock, K. 2012. "Recipes for Intervention: Western Policy Papers Imagine the Congo", International Peacekeeping 19 (5): 549-564

Koddenbrock, K. 2014. "Malevolent politics: ICG reporting on government action and the dilemmas of rule in the Democratic Republic of Congo". Third World Quarterly 35(4): 669-685.

Lewis, S. y E. Ensler. 2008. "The Never Ending War" The Huffington Post.

Malkki, L. 1996. "Speechless Emissaries: Refugees, humanitarism and dehistoricization". Cultural Anthropology 11 (3): 377-404.

Mbembe, A. 2001. On the postcolony. Los Angeles: University of California Press.

McLagan, M. 2002. "Spectacles of difference: cultural activism and the mass mediation of Tibet", en F. Ginsburg et al., Media Worlds: Anthropology on New Terrain: 91-112. Los Angeles: University of California Press.

McLagan, M. 2006. "Making Human Rights Claims Public". American Anthropologist 108: 191-195.

Moeller, S. 1999. Compassion fatigue. How the media sell disease, famine, war and death. Nueva York: Routledge.

Médicos Sin Fronteras. 2014. La emergencia que no cesa. Sufrir en silencio en República Democrática del Congo. Barcelona: Médicos Sin Fronteras

Newbury, D. 1996. "Convergent Catastrophes in Central Africa". Review of African Political Economy 23 (70): 573-576.

Nordstrom, C. y A. Robben. 1995. Fieldwork under fire. Contemporary studies of violence and survival. Los Angeles: University of Los Angeles Press.

Olujic, M. 1998. "Embodiment of terror". Medical Anthropology Quarterly 12 (1): 31-50.

Pedelty, M. 1995. War Stories: The Culture of Foreign Correspondents. London: Routledge.

Prunier, G. 2009. From Genocide to Continental war. The "Congolese" conflict and the crisis of contemporary Africa. London: Hurst.

Redfield, P. 2006. "A less modest witness: Collective advocacy and motivated truth in a medical humanitarian movement". American Ethnologist 33 (1): 3-26.

Redfield, P. 2012. "Humanitarianism", en D. Fassin (ed.), A Companion to Moral Anthropology: 451467. Malden: Blackwell.

Rozario, K. 2003. "Delicious horrors': Mass Culture, the Red Cross and the Appeal of Modern American Humanitarism". American Quarterly 55 (3): 417-455.

Scarry, E.1985. The body in pain. The Making and the Unmaking of the World. Nueva York: Oxford University Press.

Scheper-Hughes, N. 1995. "The Primacy of the Ethical: Propositions for a Militant Anthropology". Current Anthropology 36: 409-20.

Scheper-Hughes, N. y P. Bourgois. 2004. Violence in War and Peace: An Anthology. Oxford: Blackwell Publishers.

Stearns, J. 2012. Dancing in the Glory of Monsters: The Collapse of the Congo and the Great War of Africa. New York: PublicAffairs.

Wax, E. 2004. "A brutal legacy of Congo war: extent of violence against women surfaces fighting recedes". Reproductive Health Matters 12 (23): 181-182.

WorldCom-LolaMora. 2008. Justice for women: seeking accountability for sexual crimes in post-conflict situations. Bruselas: FRIDE.

Fecha de recepción: 15 de enero de 2015

Fecha de aceptación: 2 de marzo de 2015 